\title{
Evaluation of Community Based Medical Education Program in Bezmialem Vakıf University Faculty of Medicine Education
}

\section{Bezmialem Vakıf Üniversitesi Tıp Fakültesi Eğitiminde Topluma Dayalı Tıp Eğitimi Program Uygulamalarının Değerlendirilmesi}

\author{
(D) Semra ÖZÇELIK ${ }^{1}$, ID Ceyda ACAR², id Bedia ÖZYILDIRIM²
}

${ }^{1}$ Bezmialem Vakıf University Faculty of Medicine, Department of Medical Education and Informatics, İstanbul, Turkey

2Bezmialem Vakıf University Faculty of Medicine, Department of Public Health, İstanbul, Turkey

\begin{abstract}
Objective: The World Health Organization, National and international accreditation bodies emphasize that physician candidates should also receive training in environments where they can see and recognize the health problems and health system of the society in which they live. The aim of this study is to evaluate community-based medical education practices in Bezmialem Vakıf Faculty of Medicine education program.
\end{abstract}

Methods: Beginning from the first period of our medical education for community based medical education and community recognition program practices; visits to community health centers, family health centers, childrens' houses from social work instutitions, hospice, tuberculosis dispensary, as well as Bezmialem Public Health Days as an education and service project in society and the Forensic Medicine Institute has been planned as application areas. All applications were made in the training program on predetermined dates and the feedbacks received from the students were evaluated using the thematic analysis method. The feedback of each program was evaluated as a separate category and analyzed on the themes of education efficiency, fitness for purpose, adequacy of the organization.

Results: The students expressed their satisfaction with these educational activities and community visits to the community. However, they stated that the applications in the pre-clinical period were close to exam dates, problems such as disruptions in transportation, that they wanted to communicate with more people in the institutions they went to and that the applications should be extended for a longer period of time.

\section{ÖZ}

Amaç: Dünya Sağlık Örgütü, Ulusal ve Uluslararası Akreditasyon Kuruluşları, hekim adaylarının yaşadıkları toplumun sağlık sorunlarını ve sağlık sistemini görebilecekleri, tanıyabilecekleri ortamlarda da eğitim almaları gerektiğini vurgulamaktadır. Bu çalışmada, Bezmialem Vakıf Üniversitesi Tıp Fakültesi eğitim programında yer alan topluma dayalı tıp eğitimi uygulamalarının değerlendirilmesi amaçlanmıştır.

Yöntemler: Topluma dayalı tıp eğitimi ve toplumu tanıma program uygulamaları için tıp eğitimimizin ilk döneminden itibaren; toplum sağlığı merkezleri, aile sağlığı merkezleri, sosyal hizmet kurumlarından çocuk evleri, darülaceze, verem savaş dispanseri ziyaretleri yanı sıra toplum içinde eğitim ve hizmet projesi olarak; Bezmialem Halk Sağlığı Günleri ve Adli Tip Kurumu uygulama alanları olarak planlanmıştır. Tüm uygulamalar eğitim programında önceden belirlenen tarihlerde yapılmış ve öğrencilerden alınan geri bildirimler tematik analiz yöntemiyle değerlendirilmiştir. Her bir programın geri bildirimi ayrı bir kategori olarak değerlendirilmiş ve eğitimin verimliliği, amaca uygunluğu, organizasyonun yeterliliği temalarında analiz edilmiştir.

Bulgular: Öğrenciler, toplum içinde yapılan bu eğitim etkinliklerinden ve toplum ziyaretlerinden memnun olduklarını ifade etmişlerdir. Ancak, klinik öncesi dönemdeki uygulamaların sınav tarihlerine yakın olması, ulaşımdaki aksaklıklar gibi sorunlar bulunduğunu, gittikleri kurumlarda daha fazla kişiyle iletişim kurmak istediklerini, uygulamaların daha uzun bir süreye yayılması gerektiğini belirtmişlerdir.

Address for Correspondence: Semra ÖZÇELiK, Bezmialem Vakıf University Faculty of Medicine, Department of Medical Education and Informatics, İstanbul, Turkey

E-mail: semraozcelik@bezmialem.edu.tr ORCID ID: orcid.org/0000-0001-9237-6723

Received: 27.09.2019

Accepted: 07.01.2020

Cite this article as: Özçelik S, Acar C, Özyıldııım B. Evaluation of Community Based Medical Education Program in Bezmialem Vakıf University Faculty of Medicine Education. Bezmialem Science 2020;8(3):300-10. 
Conclusion: Physicians need to be aware of the health and social problems of the society in which they live and to be aware of them. It has been determined that the applications of our faculty are well integrated into the educational programs and that many of the knowledge they have gained in theory has strengthened in the application areas in the primary care. Children's Houses and Darülaceze visits have been found to be beneficial for preclinical students in terms of getting to know the community and raising awareness. The students' suggestions were discussed in the relevant boards and reflected in the next year's curriculum.

Keywords: Community based medical education, community recognition programs, community visits
Sonuç: Hekimlerinin yaşadıkları toplumun sağlık ve sosyal sorunlarını bilerek ve farkında olarak yetişmeleri gerekmektedir. Fakültemizdeki uygulamalarının eğitim programlarına iyi entegre olduğu, teorikte edindikleri birçok bilginin birinci basamaktaki uygulama alanlarında pekiştiği saptanmıştır. Çocuk evleri ve darülaceze ziyaretlerinin ise klinik öncesi öğrencileri için toplumu tanımak ve farkındalık oluşturma açısından faydalı olduğu gözlenmiştir. Öğrencilerin önerileri, ilgili kurullarda görüşülerek bir sonraki yılın ders programına yansıtılmıştır.

Anahtar Sözcükler: Topluma dayalı tıp eğitimi, toplumu tanıma programları, toplum ziyaretleri

\section{Introduction}

In order to be aware of the society in which they live, it is suggested that the candidates of physicians trained in medical education should be educated in environments where they can see the health problems and the health system of the society (1). In line with these recommendations, programs have been made in many medical schools in order to receive education outside of the tertiary education environment, and efforts have been made to ensure the recognition of the sociocultural diversity of the society and the communication with a large number of people. This suggestion is included in the National Standards of the World Health Organization, World Medical Education Federation and the National Medical Education Accreditation Board (1,2). In World Health Organization reports, in the declarations of institutions such as Medical Councel, CanMed, World Medical Education Federation; there are decisions in the form of "Medical education should primarily be able to reflect the changing nature of healthcare services and provide experience in different settings such as hospitals, primary care and community healthcare. From the beginning of the education, students should be able to interact with different people socially, culturally and ethnically" (1). On the other hand, in our country, the National Board of Accreditation for Medical Education (2018) standards include: "Medical schools must construct the education program to include the primary health problems of the society", "Medical schools must perform some of the educational activities during medical education in health institutions other than third level and in the community", "Medical schools education program should include local priority health problems of the community" (2). Education programs in medical schools in our country are prepared by taking into account the health problems that society needs and are also determined and supported by the National Core Education Program. In addition to these programs, which are planned as community-oriented education, there is also a need to achieve gains related to the needs of society through communitybased medical education programs. In these programs, learning activities are expected to actively participate in the learning experiences of educators, community members, public and sector workers, not just students as a learning universe (3).
There are important reasons why institutions that train future physicians should include community-based educational practices. Students have the opportunity to learn about similar situations in their professional lives beforehand, have the opportunity to work with medical staff in different institutions and organizations such as primary care institutions, and have the opportunity to apply competencies that they can not learn elsewhere, such as leadership, teamwork, communication skills. These practices strengthen cooperation between the university, the community, and those who form health policies $(3,4)$.

By reason of university hospitals where medical education is provided are more concerned with more specific diseases than common diseases in the society, having higher technological opportunities in diagnosis and treatment than primary and secondary care settings, lack of holistic approach in health services, and limited possibility to realize the relationship between diseases and social factors, it becomes compulsory to carry out applications in the community.

It has also been seen that early initiation of community-based medical education promotes learning and professional attitude development (4). For this purpose, many environments can be selected as application areas. For example, community health centers (CHS), family health centers (FHC), tuberculosis dispensaries, workplaces, schools, elderly hospices, secondary hospitals, health-related non-governmental organizations can be counted (2-4). In the studies related to the subject, it is also emphasized that it is important for these trainings to be given in the society in medical education to be carried out in cooperation with different disciplines. It is stated that such practices are beneficial not only for medical students, but also for other students studying in the field of health (2-5).

Currently, in order to train physicians for Primary Health Services, which are the priority of medical education in our country, attention is paid to this issue and studies and evaluations highlighting the importance of the issue are published (5-9). At the end of the applications, feedback should be received from the students, field trainers, lecturers and field health personnel in the program and all components should be observed and evaluated. 
With this view in our study; it is aimed to evaluate the reports based on community-based programs in Bezmialem Vakıf University (BFU) Faculty of Medicine Education Program and the feedbacks received from students after these practices and the program we implemented.

\section{Methods}

In the BFU Faculty of Medicine Education Program, practices have been established to inform physician candidates about the structure of the health system, to raise awareness about the activities of non-governmental organizations that are involved in health and/or social assistance, and to enable them to take part in social responsibility projects. Attention was given to giving priority to these practices at all stages of education, and importance was given to meeting with the society from the early stages of education.

When these applications are mapped by periods (classes);

a. Raising awareness about FHC, Red Crescent and its activities in term I,

b. Visits to children's homes from social work institutions in term II,

c. Visit to hospice and education and service project in the community with the name "Bezmialem Public Health Days" in term III

\section{d. Tuberculosis Dispensary in term IV,}

e. Forensic Medicine Institution in term V,

f. Term VI is planned as training in CHS and FHCs.

Regarding the applications, official correspondence was made with the institutions, necessary information was made by contacting the municipalities and Health Directorates, permits were obtained and student lists were reported to the relevant institutions prior to the activities. All meetings and correspondence with the institutions were made by The Deanery and clear information was obtained about who to contact. Students were informed by meeting before each event and asked to carefully fill out the activity and feedback forms given to them.

In the FHC visit program implemented in period I, approximately thirteen ASM visits were made, directed by the District Health Directorates in Bayrampaşa and Zeytinburnu. Students are divided according to unit numbers (physician numbers) in FHCs. Some FHCs had 2-3 students while others had 8-9 students. These groups are divided by the respective District Health directorates such that one student is assigned to each FHC physician. The students who were divided into groups and taken to these centers received information from the physicians responsible for the center and observed the work of the physician. Students observed the functioning of FHC during their stay and were asked to write their learning about the functioning and their feedback on the program in free text. They submitted these reports to the Department of Medical Education and Informatics. Red Crescent, another activity in term I, attempted to raise awareness about the activities of this institution and the benefits they provide to the society. The presentations made by the authorities were interactive with the students and the students were asked to give a report containing their feelings and thoughts on the subject. A total of 146 students attended the event in the 2018-2019 academic year, having attended the first grade.

Students visited four different FHCs in groups in the FHC visiting program which was implemented in term II. Similar to the visit schedule in term I, the visit of FHCs in Bayrampaşa and Zeytinburnu consists of receiving information from the responsible persons and monitoring the services in FHCs. In the term II, there was also a visit to children's houses from the important social service institutions of our country and three different children's houses (Kasımpaşa, Bahçelievler and Zeytinburnu children's houses) close to our campus area. The students were shared equally among these three institutions, and one person from the term II coordinator and assistant and the Dean's Office of Student Affairs went to the institutions with the students. During the visit, students were informed about the activities of the institution and its benefits to society, asked to make observations and give feedback by writing reports. A total of 120 students attended the event in the 2018-2019 academic year, having attended the second grade.

In the program of visit to the aged care homes, which was implemented in the term III, Darülaceze, an old institution known since the Ottoman period, was visited, the institution officials provided detailed information to the students, and the students were allowed to communicate with the elderly, make observations, prepare reports and provide feedback. In this collective visit, the students were accompanied by a semester III coordinator and an officer in charge of Student Affairs of the Dean's office.

In order to organize the social responsibility activity implemented in term III, (Bezmialem Public Health Days), term III Coordinator and Assistant, as well as Medical Education and Informatics, Public Health, Child Health and Diseases, General Surgery, Gynecology and Obstetrics, Chest Diseases and Family Medicine assistant professors and/or research assistants and interns' assignments were made. An organizational team was established with the participation of faculty members and/ or senior students from the Physiotherapy and Nutrition and Dietetics Departments from the Faculty of Health Sciences. The aim of the program is to provide students with practical learning to serve in the community. The learning objectives of this event are to develop communication skills in society, to learn common health problems in society, to recognize other institutions, staff and functions in the field of Community Health and to develop their knowledge and experience about these issues. During the preliminary preparation process, numerous meetings were held regarding the content of the program. During the meetings, the lecturers responsible for the control of the tents, their duties and days were determined. In addition, the contents of the brochures were prepared by the departments and the organization team related to the determined activities and printed by The Deanery. According to the program, in Eyüp Square, students 
provided services for the public in six tents where some basic measurements, trainings and brochure distribution were carried out in the fields of women's cancers, nutrition, physical activity, diabetes, blood pressure, respiratory disorders. In these tents, informations about breast and cervical cancers, self-examination of breast examination, healthy nutrition education, body mass index measurement, spirometry measurement, glucose and blood pressure measurements and informations were made and brochures were distributed. In each tent, a faculty member and a research assistant were responsible for their own subject everyday and checked the information and measurement of the students. In all activities, students have gained skills by communicating with the community, directing and informing people on common health problems. Students had the opportunity to practice in this program what they had previously learned during basic medical skill hours when they were in first and second grade. The students were informed about the program in advance and the class representative was invited to all the meetings held before the program and their opinions were received. Tents provided from various institutions were set up in the very crowded square of Eyüp district. Transfer of students to the field was provided with the necessary tools and equipment. The practice started at 9:00 for five days and lasted until 17:00.

Selected topics at the beginning of the project;

a. Information about common cancers in women,

b. Breast examination,

c. Family Practice (blood pressure, glucose measurements etc.)

d. Body mass index calculation,

e. Doing respiratory function testing with spirometry.

The rotation of the students to take part in each topic is planned and thus it is aimed that each student will gain skills with the applications he/she performs in each activity. Students were asked to communicate directly with the people who visited the tents and to record every action they performed. In some applications, students in Physiotherapy and Nutrition and Dietetics also participated in the work in tents. Eyüp district Health Directorate observed the activity and informed them again about what was being done. The event was attended by all 98 students who were in third grade during the 2018-2019 academic year.

In term IV, our students are grouped together to attend Tuberculosis dispensary every week as one day per week during the internship of the Department of Child Health and diseases. The students are informed about the operation and the procedures. It is practiced as a primary care rotation within the internship. Feedback from students about their observations here is taken together with internship feedback and evaluated. A total of 131 students enrolled in fourth grade during the 2018-2019 school year participated in this rotation.

In term V, our students go to Forensic Medicine Institution in forensic medicine internship and receive education and information about the functioning of the forensic medicine applications in their own place. It is the practice of rotation within the internship. A total of 131 students enrolled in fifth grade during the 2018-2019 academic year.

In the training of term VI, interns in Public Health Applications are provided to do rotation internships in Provincial Public Health Services and District Health Directorate/Community Health Centers. Family medicine practices are carried out in all Family Health Centers within the District Health Directorate/ Community Health Center. During the 2018-2019 academic year, a total of 132 students enrolled in the sixth grade attended these practices.

In public health internships, students were trained in the Public Health Services Department of the Provincial Health Directorate for one week. During these practices, students were distributed to different units each day from Family Medicine Environmental Health Infectious Diseases, Child, Adolescent and female reproductive health, vaccine programs, cancer, mental health departments and received seminars about what works are done and how they are done. In cancer early diagnosis screening and education center, child, adolescent, woman and reproductive health, healthy life center, infection control, occupational health safety, diabetes and obesity, migrant health center and health center in Bayrampaşa and Zeytinburnu District Health Directorates, they learned the work done in their units in the form of a seminar for one week. Also infectious diseases, immunization and outbreak control, tuberculosis control services, non-communicable diseases and services for the control of obesity, women's health and reproductive health services, environmental health services, in-service training services in the areas of public life, and school health services, oral health services, child and adolescent health services, early detection of cancer, screening and education services in terms of field studies participated in this survey.

In the study, feedback from the students reached all communitybased activity evaluations in the BFU Faculty of Medicine Program. The reports were prepared at the end of the program in a free-form text, not through specific questions, in which the students' opinions on the program were taken and their observations summarized. The effects of these educational activities in the community on the students, their feelings, thoughts and suggestions regarding these programs, were obtained by the observation reports they prepared.

Verbal feedback is always received from the institutions related to the practices and from the trainers and observers involved in the trainings.

Reports were taken separately for each program and each program was considered a different category. The contents of the reports are discussed in the headings: efficiency of applications and observations in terms of content, fitness for purpose in terms of teaching practices and observations, competence of the organization. 


\section{Results}

\section{FHC Visits (Term I and II)}

FHCs, as primary health care institutions, aims to ensure that medical school students can learn preventive health services from a societal perspective. FHC visits were based on the "Cooperation Protocol between the İstanbul Governorship and BFU (SEAB Protocol)" signed between the ministry of health and our university, official correspondences were made beforehand and the areas of application were tried to be close to the campus area and students were grouped and visit was accompanied by a responsible person.

Information such as the characteristics of ASMs, working principles, competencies, job descriptions of the staff were explained by ASM personnel and then distributed to the physicians who performed the outpatient clinic examination for observation. Physicians transferred their procedures, Anamnesis and patient examinations to the students according to the status of the incoming patients and chatted with the young people to learn from their experiences and some of the events they had experienced before. The students have learned a lot during the visit and have reported that their education has been productive.

"I think it was very useful. I think it was very important to be able to watch and observe what he did next to a family physician and even experience it with the help of a substitute. Personally, I'd like to come for longer periods of time"

The main purpose of FHC visits; in general, it is aimed to enable students to learn the objectives, management and scope of community based health services. Students' feedback on the suitability of FHC visits for their purpose, "I learned information such as who managed FHC, where it gets its budget", are included in the statements. It is understood that they can develop awareness about the operation and management in FHCs. FHCs contain different diseases and patient profiles as the first health centers that the society applies to. Other special services of FHC outpatient clinics are that family physicians serve a certain population in FHCs.

In addition to functioning and management, students also observed special situations in the outpatient services of the family physician. Students who stated that they can get the information about the functioning of the instution, which is one of the most important goals of the visits, "I had the opportunity to see how FHC works and serves" as stated, the visits showed that the students gained information suitable for the purposes.

Family physicians working in FHC have administrative responsibilities such as information transfer, management and training responsibilities in addition to performing medicine related to outpatient procedures. It is seen that students also benefit from these educator roles of Family Physicians.

"I had the opportunity to observe my profession at the FHC where I came from. The most conspicuous features are that the physician greets his patients with a smiling face, questions their complaints and examines them with great care. He responded meticulously to the questions I asked, and invited me to attend a one-to-one examination. There were too many patients. The doctor saw me as a colleague and said I could come by whenever I wanted. I had an observation that I enjoyed. I had fun, learning new information. It was a beautiful day".

Observations on the patient-physician relationship that all physicians have to internalize have also benefited students.

"During the visit we saw what the patient-doctor relationship should be like. We listened to the experiences of Physicians. This visit has given us so much. We have seen our profession in the field'.

In the feedback received from the students, there were also suggestions to be taken into consideration, such as determining the dates of visits and strengthening the transportation planning, while the FHC visits carried out within the scope of social responsibility could be carried out more efficiently and effectively.

"We had a service problem. Driver had difficulty finding $F H C$ ".

"It was very bad that this practice was close to our committee exam".

He said: "I think it was unnecessary, it was never good to have it in committee exam week".

In all FHC practise, team I and II visited on separate dates. The students did not have any criticism other than timing. On the contrary, the vast majority stated that this practice was beneficial and their satisfaction with the observations they made on the spot. The decision to continue this practice next year, but not to exam weeks, was taken in the relevant boards.

\section{The Red Crescent Awareness Study}

The Red Crescent is an international and ancient institution of Turkey that provides social assistance in terms of social determinants of health. This institution has studies that have direct or indirect effects on health in many areas such as fundraising, awareness, humanitarian aid, disaster relief. While determining the program to be carried out in The Red Crescent, correspondences were made with the Fatih branch of the institution. It was decided by discussing with the officials of the institution what things can be done to get the Term I students to have detailed information about this institution works in the public interest. Due to the large number of students, it was decided to inform the students with an interactive presentation. 129 students participated in the activity and provided feedback reports.

Five people from the physician and administrative staff who are in charge of Kizilay Fatih Branch Presidency informed our students with this interactive presentation. In students' reports, it is reported that in this meeting they were both informed and received their answers under various topics such as the history of the Red Crescent, its activities, blood donation, stem cell donation, volunteering, scholarships, and the Young Red Crescent.

Students expressed their opinions regarding the efficiency of the activity; 
"Although it is an impressive and informative event, I can say that it has increased my willingness to volunteer at the Red Crescent in the future".

The purpose of social responsibility projects is to enable students to realize their social responsibilities from the public health perspective while performing their medical duties and to guide their patients with this awareness while performing the medical profession. It was understood that this learning goal was achieved with the feedback of the students. As Demirören stated in their study, the students in faculty of medicine should be able to understand social responsibility in depth (6). One of the goals of the Red Crescent visit is to enable students to see the healthrelated social service activities on site in order to gain social responsibility. Students expressed their views on the suitability of the visit to their learning goals as follows;

"First of all, I am aware that I have learned better the duties and the points of the Red Crescent. I was impressed and proud of the development of the Red Crescent. As a human being, I realized that I should be more sensitive about these issues. Thank you".

Sensitivity to social problems and issues is a merit that should be developed in accordance with the physicians' missions to protect public health. Students stated that their sensitivity towards social problems increased during the activity. The role of the health defender, which is among the graduate qualifications of the BVU Faculty of Medicine; is "to improve the health of individuals and society, to understand their needs, to work with them to meet their needs, to advocate when necessary, and to contribute to creating resources to create a change or to be a driving force". It is revealed from the following statements that students develop social sensitivity with this visit and make internalized decisions towards health advocacy;

\section{"My friends and I decided to volunteer for blood donation and bone} marrow donation".

"I liked the event very much. Thanks to this activity, I learned a lot about the Red Crescent. I learned how to volunteer and decided to volunteer. The speeches were very friendly and sincere, I could watch it carefully".

Developing students' sensitivity is very important in terms of medical education, community based medical education practices as a learning objective.

\section{Children's Shelter Site Visits}

Children's shelters are institutions where children under the age of 18 need protection and care sheltered. Within the scope of social responsibility programs, it is aimed that the students can see the health service needs of the children's shelter site and the areas where the physicians can fulfill their social role.

After the official correspondence, the students were taken to the three different children's shelters with shuttle services. Kasımpaşa, Bahçelievler and Zeytinburnu Children's Shelter Sites, which are close to the University Campus area, were visited together with the responsible lecturers. An informative meeting was held for our students by the officers, teachers and physicians of the institutions, and the students were enlightened with the answers to their questions. The students stated that the program was efficient with the excess of information they learned during the visit.

"It was an interactive practice. I learned a lot about children's homes, my prejudice was broken".

It is also understood from the feedback received that the students' sensitivity and awareness about children in the children's shelters has increased.

"We encountered a very cute and warm environment. Although we could not meet with the children directly, we observed the environment they stayed in, social activities and the areas they had fun",

It is understood from what they say that students have mastered the studies of health-related institutions. The details they give about the content of the visit shows that it is effective for students to gain awareness, which is the purpose of education.

"I saw that children's shelters are very different from those pictured in the media. All kinds of their needs are considered, they even have clinical psychologists."

Students also had some suggestions about the organization. This shows that students' participation in the education program is strong.

"We couldn't meet the kids. I wish it was a different organization like picnic".

It is seen that they have requests to communicate directly with the society that they are likely to serve. This makes us think that students' social sensibilities are also improving.

\section{Darülaceze (Poorhouse) Visit}

Darulaceze is an institution that carries out the duty of caring for people in need since its foundation. Information about the location of the institution, where basic needs were met and health support was received, and how the health and social needs are met, and awareness was raised.

Students studying in Term III visited Darülaceze, one of the well-established institutions of our country, based on a voluntary basis. On the specified day after the official correspondence with the institution, 25 students were taken to the visit with their coordinators. The students were informed by the institution officials about the purpose of the institution, who benefited from them, their accommodation opportunities, job and skill activities, and they were allowed to communicate with the individuals living in the institution. The aim of the program is to increase social sensitivity and awareness and to make students aware of the social responsibilities of physicians in environments where social service and support are collectively provided to individuals at different stages of life. The students provided feedback about the efficiency of the program, thus gaining this awareness. Students have provided feedback on gaining this awareness and therefore the efficiency of the program. 
"As a candidate for physician, it was very important for me to communicate with the elderly in this institution. I recommend it to be more comprehensive and done every year."

Students have started to present new ideas and projects with the responsibilities they undertook under favour of the visits. It seems possible that these ideas can be realized later as student club activities.

"Darülaceze is an institution established by Abdülhamid the $2^{\text {nd }}$, for the protection of people in need due to the intense migration after the Ottoman-Russian war. We met some of the remaining residents. They make handcrafts and they sell them. Every resident takes place at an event. I learned a lot that I had not not know before, in this activity. But we need to communicate more with the individuals there. I had an idea; we have to create a project and spread it over the whole year. We can work all day at the Darulaceze event building. I would like such events to be more frequent".

The fact that students have developed social sensitivity and awareness of the working objectives of the institutions shows that the learning objectives of the program have been reached.

\section{Social Responsibility Week}

This activity, which was initiated under the name of Bezmialem Public Health Days and traditionally planned every year, was carried out with the participation of all Term III students (Figure 1).

The content of our event was announced and the necessary permits were obtained from the authorized institutions such as the Provincial and District Health Directorate and Eyüp Municipality. Public examinations and trainings were held in Eyüp Square in line with the program details determined as one week in our training program. Brochures prepared in these trainings were distributed to the public (Figure 2).

In the tents set up in the Eyüp District Square, for a week, examinations and information were provided for protection against diseases of different themes (briefing about the common

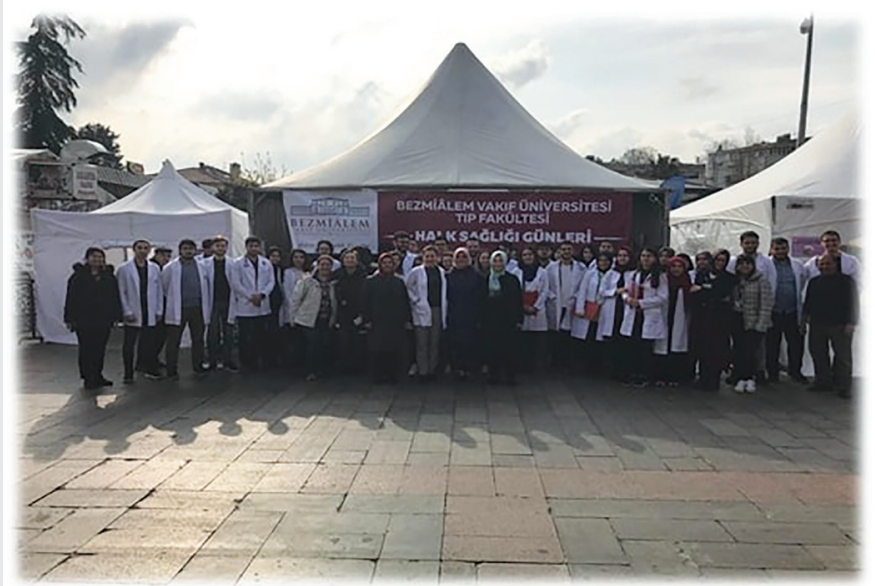

Figure 1. Students and faculty members in Bezmialem public health days event cancers in women, breast examination, family medicine practices, blood pressure and diabetes measurements, body mass index calculation, spirometry and respiratory function test). These include physical examinations and respiratory function tests, blood pressure, sugar and weight measurements, diabetes, growth and development in children, nutrition and vaccine information, and briefing on the importance of cancer screening.

The efficiency of the program;

"Helping people and raising their awareness about healthy living made me happy".

Dilekmen stated that according to the learning theory, students acquire problem solving skills in real life while in social interaction (8). It can be thought that basic medical skills also developed in this context.

\section{"It helped me gain basic medical skills".}

The aim of this program is to teach students how to serve in the community. Figure 2 shows students' pictures in the activity (Figure 2).

It is understood from the achievements that the education program contributes to the development of skills such as communication, teamwork, and social sensitivity, which are aimed in the Public Health Days program, and that the students stated they especially developed;
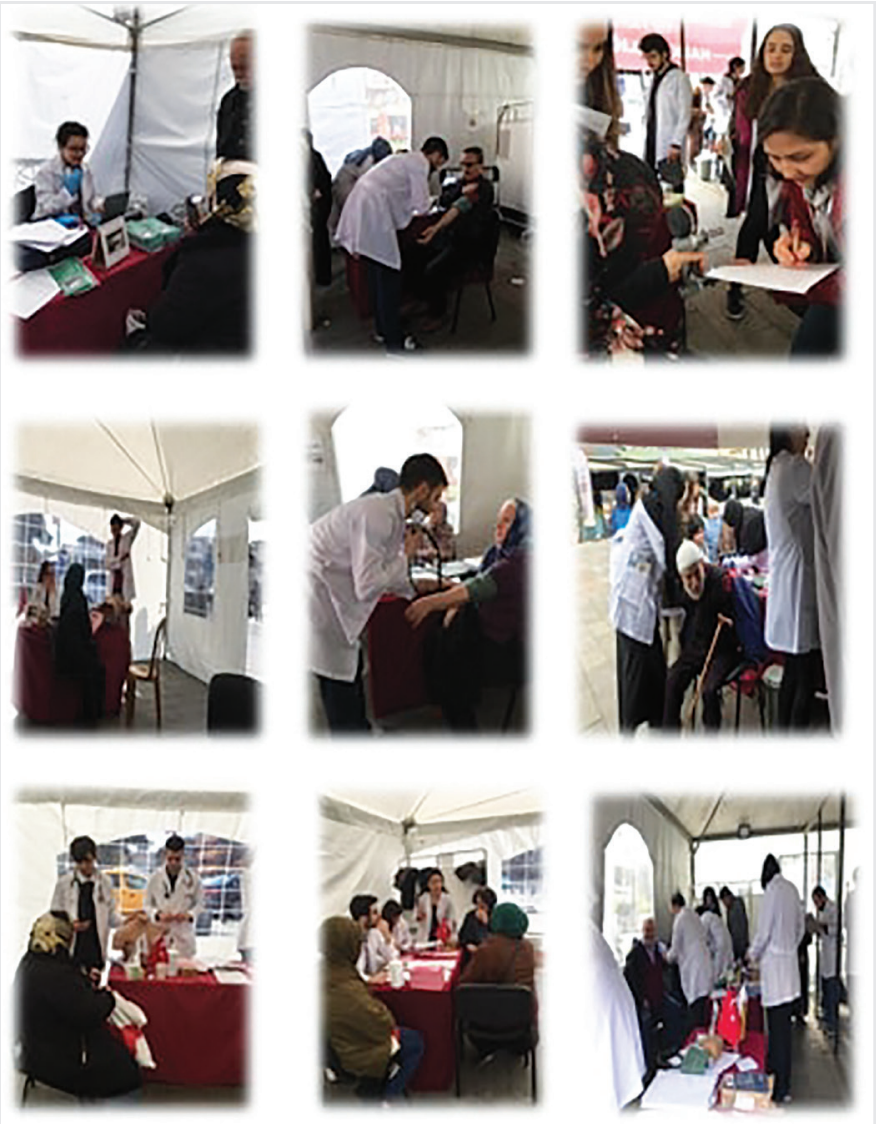

Figure 2. Student practices in Bezmialem public health days events 
"I made gains in terms of patient physician dialogues".

"It was a beautiful environment where we implemented teamwork and cooperation".

"I think my communication with both the community and my group friends has improved".

In their feedback, the students stated that they could learn to be able to serve in the community and learn about communication, and made suggestions that would contribute to the development of the program.

Students show that in their feedback to the organization, a participatory training was carried out with some criticism of inventory and planning.

"It was a very nice event, I wish it was held every year. But there were some shortcomings. The division of labor should be made to students in advance".

"The system should maturate bit longer".

"The number of spirometers should be high".

"It can be measured in BMI in child nutrition department".

\section{Tuberculosis Dispensary}

Today, Tuberculosis Dispensaries are service units that stand at a key point in terms of preventive medicine and public health. This rotation, which is placed in the program with the permission of the relevant institutions, provides awareness of the operation in the units providing primary health care.

Term IV students performs rotation at Fatih Verem Savas Dispensary every Friday within the internship of the Department of Pediatric Health and Diseases. Students are sent regularly by grouping beforehand and reporting their names to the relevant institution. In this institution, they follow-up patients with tuberculosis with the responsible physician, interpret chest $\mathrm{X}$-rays, observe the treatments given, and they can apply the measurements of the PPD tests, and etc. under the supervision of the principals and in limited numbers.

Feedback from students about this rotation is taken with emphasis on this rotation in Pediatric Health and Diseases internship feedback. Positive notes are taken about this training. It is understood that students are satisfied with the experience gained from this primary health care service.

\section{Forensic Medicine Institute}

With the official protocols made, in the rotation of the Forensic Medicine Institution applied in the Forensic Medicine internship in Term V, all students, in groups, observe and experience the operations performed at the institution for two days.

Students, as part of our education, while they are at the Forensic Medicine Institute; they can monitor and/or apply skills such as "Forensic case examination", "Examination of deceased", "Preparing a forensic report" in the National CEP (Core Education Program).
Feedback on this rotation is taken by referring to this rotation in Forensic Medicine internship feedback. Students express very positive opinions about this experience. It is understood that the students are satisfied with the experience gained from the relevant institution.

\section{Provincial Public Health Services Presidency, District Health Directorate and Primary Care Clinic Applications}

With the protocol between the Turkish Ministry of Health and our University, "T.C. The cooperation protocol (SEAB protocol) between the governorship of Istanbul and Bezmialem Vakıf University on the establishment of a health, education and research zone", the educational zone of our university is determined as Bayrampasa and Zeytinburnu districts of Istanbul province. For this reason, the studies regarding the education and research that our Faculty of Medicine will conduct with the Ministry of Health are carried out in Bayrampaşa and Zeytinburnu District Health Directorate/Community Health Center Region. Our interns, in groups, go to the internship in Provincial Public Health Services for a week and in Zeytinburnu and Bayrampaşa District Health Directorates/Community Health Center for a week in correspondence within the scope of the Protocol. Family Medicine internships are carried out for two weeks in Training and Research Family Health Centers (TRFHC), that is, in all Family Health Centers in Education Research District Health Directorate/Community Health Center.

Students are sent to the units that provide public health services (Vaccine Programs Unit, Contagious Diseases Unit, Employee Health Unit, Environmental Health Unit, Cancer Unit, Mental Health Unit, Healthy Nutrition and Active Life Unit) within the Provincial Public Health Services Directorate. The internships are related to the functioning of the units they are sent in line with the pre-determined learning objectives, the related units, the reflections of the unit studies in the national health system, etc. and they include the acquisition of information and the learning of the duties of physicians in the relevant institutions and units. Thus, our students learn the duties, responsibilities and authority that a physician who work at the Provincial Public Health Services Directorate should undertake.

Within the scope of the services provided in Zeytinburnu and Bayrampaşa District Health Directorates/Community Health Center; students also observed Infectious Diseases, Immunization and Outbreak Control Services, Non-communicable Diseases and Obesity Control Services, Women and Reproductive Health Services, Environmental Health Services, Mental Health Programs, Pediatric Health and Safety Services, Public Living Areas and School Health Services, Children and Adolescent Health Services, Cancer Early Diagnosis Services, as well as KETEM (Early Detection, Screening and Education Center for Cancer) Unit, ÇEKÜS (Child, Adolescent, women and Reproductive Health) Unit, Healthy Life Center, Occupational Health and Safety Unit, Diabetes and Obesity Unit, Migrant Health Center and Health House Units.

Students have the opportunity to make many observations and obtain information in the field internships they perform during 
Public Health internships. The ability of students to bring critical comments reveals the efficiency of education.

"I got an idea about the work in the field. I noticed the aspects of primary level applications that need to be improved. Family medicine assignment was efficient. DHD (District Health Directorate) was generally effective and efficient".

"My visit to District Health Directorate (DHD) was the first. I observed the functioning of the working units. I have observed that its productivity is good in units such as screening programs, family and follow-up".

The internship is considered to be more efficient because students think they have acquired the information they will benefit from in their professional lives.

"I think it is very useful. In particular, we had the opportunity to observe the Environmental Health, Cancer Unit and Mental Health as prospective general practitioners".

Students' opinions that they contribute to the awareness of their responsibilities towards the society as a physician in their professional lives are also important in terms of demonstrating the efficiency of education (6).

"When we needed to see that the Migrant Health Center was working efficiently, it was a good achievement in terms of our guidance".

"The infectious diseases unit was good. Everything was in consistency. The adolescent unit was also useful. Education was good... The education and system in the vaccine was good".

Students also evaluated the training in terms of the attitudes and knowledge of the trainers during the internship. It is seen that the trainer-student relationship, which is one of the factors affecting the efficiency of education, and the dominance of the trainer increases the efficiency of the internships.

"Vaccination, environmental and cancer units were very useful and informative. Most importantly, it was very important that they regard us as the doctors of the future and respect us".

"Those in the vaccination and environmental health units were people who had a good command of their jobs, treated us with respect and earned our respect with their interests and competencies. I felt that our time was valued, not wasted".

Students found screening programs that they actively participated in during their internships efficient. Applied trainings speed up students' learning. Students' views have also been this way.

"Newborn (NB) screening program was good and efficient".

"We learned the screenings performed in the cancer unit, we learned the role of the family doctor in this process. We learned how they monitor drinking water in the peripheral unit. We learned how to follow the cold chain and get the records in the vaccine unit".

"We were pleased with the people who were interested in us for neonatal screening program (NCP) and hearing screening".
Other opinions of students about the efficiency of the internship are as follows:

"Obesity department was productive".

"Information about heel blood monitoring and vaccination; especially the Family Medicine unit was efficient".

In this internship, our students have gained a Public Health perspective by going out of the clinic-oriented trainings and observing the duties taken by the physicians in the health services offered for protecting and improving health in the field.

Family Medicine internships are carried out for two weeks in Training and Research Family Health Centers (TRFHC), that is, in all Family Health Centers (ASM) in Education Research District Health Directorate/Community Health Center. Students were provided to learn how health data is processed and how our health system works in primary care.

It is understood from the following expressions of the students that internships can reach their learning goals:

"We had the opportunity to examine the units in the units we see in the Provincial Health Directorate on a district basis and we saw the places where the doctors worked".

"We learned about the issues covered by DHDs (District Health Directorate)".

The efficiency of the trainings increases with the motivation of the students and their motivation by believing in the benefit of the educational content (8). In a study carried out at Suleyman Demirel University, the results of the scores given over 1 to 10 points in the question about "the status of the medical education they have received is serving the duty they are doing now" have been obtained over 6.4 points (9). BVU Faculty of Medicine Term IV students also reported that the efficiency of their education was quite high due to their internship in an institution where there is a possibility of working in after their graduation.

"What does a general practitioner do at DHD (District Health Directorate) and what are their daily routines, it is much better to observe these live than to hear them. After all, even if we pass TUS (Examination for Specialty in Medicine), we will have to do these work for a while. It was good to see in advance, it would be better if the physical conditions were sufficient. I think that the field duties are very useful and contribute a lot at the professional point. This period could be increased a little more".

The students' interest in this internship was intense because they had performed an internship while they were students in the institutions where they will be assigned to after their graduation. The observation of students about the environment they will encounter in post-graduate assignments and the work they will do reduce their anxiety about post-graduation period.

"Seeing the functioning of an institution that we are most likely to be appointed to".

"I learned how to track and keep statistics on contagious diseases. I have seen the rehabilitation center facilities on site". 
"Learning our professional obligations, especially in contagious diseases, office work may be a small but an important detail that was ignored throughout our education".

The fact that students give unit names, observations and information they have learned in the feedback is an indication that students have had an efficient internship. It is seen that our students comprehend the studies they observe in every units and their importance in our health system and understand the importance of primary health care services as physicians.

"I was in the immigrant department. Such a service for foreigners was quite satisfying".

During the internships at Provincial Public Health Services Directorate and the District Health Directorate, students have the opportunity to observe the institutions and areas where their post-graduate appointments will take place, where preventive studies and health advocacy are carried out. It is understood that students have mastered their learning goals in internships and benefited from trainings for these purposes. Compilation or meta-analysis studies obtained from studies dealing with community based medical education practices also support these findings. In the data obtained from a compilation study evaluating 72 single cohort or cohort studies, it was determined that "the majority of the graduates and students receiving education from the education programs that include community based education practices were positively affected by the rural medicine experience and the education they received in primary care units". It is understood from the feedback that these students value their primary care areas (10). We believe that the reflections and benefits of our practices will be better determined with BVU Alumni feedback.

In another review study evaluating fifteen studies published between 2000 and 2009, it was stated that students selfassessed in primary education settings, and this contributed to their professionalism development with reflection (11). In the feedback reports of BVU students, similar expressions were included in which the students expressed themselves, the quality of their education, their perceptions and feelings.

There is no single concept for Community Based Education. "Educational programs", which are among the subgroups of community based education, consist of two main items: 1 . Programs for primary health care and 2. Community recognition programs (12). Both were included in the BVU Faculty of Medicine education program. In the Public Recognition Programs, students are often required to observe or participate in data collection within a limited time. For this purpose, places close to university, community or primary level institutions are preferred for this purpose. This approach was also used in the education program of BVU Faculty of Medicine.

\section{Results}

Regarding all of the community based learning practices carried out in the BVU Faculty of Medicine education program;
1. A significant awareness has been raised by encountering the health and social problems of the society in the early periods,

2. Based on their experiences, they have confidence in their communication skills,

3. They will be able to comply with team work in activities they have done together with professional groups such as nutrition and dietetics and physiotherapy,

4. We found that student-faculty communication increased in all activities with the support and participation of faculty members.

\section{Conclusion}

As a result of the positive feedbacks and evaluations received from these practices, we believe that the community based medical education activities and community recognition programs implemented in our faculty should be maintained, extended and continued.

\section{Ethics}

Peer-review: Externally peer reviewed.

\section{Authorship Contributions}

Concept: S.Ö., C.A., Design: S.Ö., C.A., B.Ö., Data Collection or Processing: S.Ö., C.A., Analysis or Interpretation: S.Ö., C.A., B.Ö., Literature Search: S.Ö., C.A., Writing: S.Ö.,C.A.

Conflict of Interest: No conflict of interest was declared by the authors.

Financial Disclosure: The authors declared that this study received no financial support.

Acknowledgment: The implementation of the above activities such as rotation and internship requires serious effort and preparation. We would like to thank all the dean's staff who contributed to these events and the Term III Coordinator and their assistant Doç. Dr. Şeyma Yıldız and Dr. Ganime Çoban who showed great effort and effort in carrying out the "Bezmialem Public Health Days" event and the class coordinator, assistant coordinators, faculty members and research staff who are involved in the project and all activities, rotations and internships. We would also like to thank the class representatives, who always support us in all kinds of events, and our students who have directed us by writing their sincerely feedbacks at the events.

\section{References}

1. WHO. Community-based education of health personnel : report of a WHO study group [meeting held in Geneva from 4 to 6 November 1985] Erişim tarihi 23.08.2019 https://apps.who.int/ iris/handle/10665/41714

2. UTEAK, Mezuniyet Öncesi Tıp Eğitimi Ulusal Standartları 2018 Erişim tarihi 23.08.2019 http://tepdad.org.tr/ uploads/files/ Belgeler\%20ve\%20formlar/5word- 
3. Bahar-Özvarış Ş. Community Based Medical Education. Toplum Hekimliği Bülteni 2007;26:1-6.

4. Bakırcı N. Toplum içinde Öğretim. Tıp Eğiticisi El Kitabı. İçinde: Sayek İ. Ankara: Güneş Tıp Kitabevleri; 2016.p.169-78.

5. Aytekin NT. Topluma Yönelik - Topluma Dayalı Tıp Eğitimi. Uludağ Üniversitesi Tip Fakültesi Dergisi 2002;28:53-6.

6. Demirören M. Medical Education and Social Responsibility. Sürekli Tip Eğitimi Dergisi 2019;28:137-44.

7. Yörünmez Dursun A. Community-Based Medical Education as an Example of PostModern Constructivist Practices. Tip Eğitimi Dünyası 2019;18:50-61.

8. Dilekmen M, Ada Ş. Motivation in Learning. Kazım Karabekir Eğitim Fakültesi Dergisi 2005;11:113-23.
9. Kolcu G, Önal Ö, Öngel K. Evaluation of the Views of Graduates of Suleyman Demirel University Faculty of Medicine 2017-2018 on Pre-graduation Medical Education Program. Smyrna Tip Dergisi 2018:35-9.

10. Barrett FA, Lipsky MS, Lutfiyya MN. The Impact of Rural Training Experiences on Medical Students: A Critical Review. Acad Med 2011;86:259-63.

11. Ladhani Z, Scherpbier AJJA, Stevens FCJ. Competencies for undergraduate community-based education for the health professions -- A systematic review, Med Teach 2012;34:733-43.

12. Magzoub ME, Schmidt HG. A Taxonomy of Community-based Medical Education. Acad Med 2000;75:699-707. 